\title{
ON THE INSTITUTION OF THE MORAL SUBJECT: ON THE COMMANDER AND THE COMMANDED IN NIETZSCHE'S DISCUSSION OF LAW
}

\author{
Peter Bornedal* \\ bornedal@hotmail.com
}

RESUMO $O$ artigo discute como Nietzsche compreende a instituição da lei e da moral em distinção a Kant e à tradição cristã. Ele argumenta que Nietzsche é, em grande medida, inspirado pela mudança de paradigma em direção a um pensamento biológico evolutivo, introduzido por diversos de seus colegas ao final do século XIX, entre os quais $F$. A. Lange, que vê esta mudança como uma sóbria alternativa científico-materialista a Kant. Em Nietzsche, a imperativa moral kantiana é substituída pela noção de uma moralidade emergente graças a processos civilizatórios históricos ou pré-históricos, impostos a um ser humano de mente débil sem quaisquer disposições racionais inerentes a obedecer à Lei. Ela também é um processo que, em vez de universalizar o ser humano, o cinde em uma dualidade, em que uma parte obedece a antigos e imediatos interesses próprios, e a outra parte obedece a novos 'comandos', que lhe foram gritados 'aos ouvidos' por um chamado 'comandante'. A obediência à lei conduz a duas formas radicalmente diferentes em Nietzsche: individuos servis e mediocres precisam ser expostos à disciplina e à punição, para adotar a Lei; enquanto os chamados individuos 'soberanos'são capazes de impor a lei a si mesmos. A figura do 'soberano'vem consequentemente sendo o motivo de vigoroso debate, especialmente quanto à tradição anglo-saxônica em pesquisa por

* Professor da American University of Beirut. Artigo recebido em 28/07/2013 e aprovado em 05/11/2013. 
Nietzsche, uma vez que seu aparente 'respeito pela lei' e 'senso de dever' reiteram típicas qualidades kantianas. Em relação a essas discussões, sugiro que o 'soberano'de Nietzsche (em um contexto) seja idêntico ao 'comandante' (em outros contextos). Quando o 'soberano', como tal, impõe a lei a si mesmo e aos demais, sua ação é convencional e arbitrária (como a linguagem em Saussure), e é mais irracional que racional, como em Kant. Sua vontade não é uma vontade boa, nem uma vontade racional, com visão para a autonomia humana. Seu comando de si mesmo e dos outros é performativo, portanto, sem valor de verdade (como atos ilocucionários de fala em Austin e Searle).

Palavras-chave Nietzsche, Kant, F. A. Lange, indivíduos soberanos, lei moral, naturalismo.

ABSTRACT The article discusses how Nietzsche understands the institution of law and morals in distinction to Kant and the Christian tradition. It argues that Nietzsche to a large extent is inspired by the paradigm-shift toward a evolutionary biological thinking introduced by several of his peers in the late $19^{\text {th }}$ century, among else F. A. Lange, who sees this shift as a sobering scientific-materialistic alternative to Kant. In Nietzsche, the Kantian moral imperative is replaced with a notion of a morality emerging thanks to historical, or pre-historical, civilizational processes, imposed on a feebleminded human without any inherent rational dispositions to obey Law. It is also a process, which rather than universalizing the human, splits it in a duality where one part obeys old immediate self-interests and another part obeys new 'commands,' having been shouted 'into the ear' by a so-called 'commander.' The compliance with law takes two radically different forms in Nietzsche: servile and mediocre individuals need to be exposed to discipline and punishment in order to adopt Law; while so-called 'sovereign' individuals are able to impose law upon themselves. The figure of the 'sovereign' has consequently been an issue for vigorous debate in especially the AngloSaxon tradition of Nietzsche research, since his apparent 'respect for law' and 'sense of duty' reiterate typical Kantian qualities. Relating to these discussions, I suggest that Nietzsche's 'sovereign' (in one context) is identical his 'commander' (in other contexts). When the 'sovereign' as such imposes law upon himself and others, his act is conventional and arbitrary (like language in Saussure), and is rather irrational than rational as in Kant. His will is not a good will, nor a rational will with a vision of human autonomy. His command of himself and others is a performative, thus without truth-value (like illocutionary speech-acts in Austin and Searle). 
Keywords Nietzsche, Kant, F. A. Lange, Sovereign individuals, moral legislation, naturalism.

\section{Lange Contra Kant on Moral Law}

Kant famously believed in a "moral law within us" that demands our respect and admiration no less than the "starry heavens above us." This moral law "within us," he regarded as part of our transcendental make up. It is a morality that makes us into autonomous and conscientious beings, and raises us above the brutes in their pure sensibility: "it infinitely raises my worth as an intelligence by my personality, in which the moral law reveals to me a life independent of animality and even of the whole sensible world."

In the last chapters of his monumental "A History of Materialism", Lange discusses the possibility of rethinking Kant's Ethics along the lines of his socalled 'Theoretical Materialism.' Like many of his peers, Lange is, on the one hand, immersed in the Kantian paradigm, but is on the other hand embracing the evolutionary biological paradigm-shift that had been introduced by Darwin, Huxley, Haeckel, and others. Lange's chapter on Darwin in "A History of Materialism" is a strong endorsement of this paradigm-shift in $19^{\text {th }}$ century thinking. ${ }^{2}$

The evolutionary paradigm becomes the foundation for this new orientation toward Materialism, which by Lange and his contemporaries is seen as modifying Kant's a priori categories. According to Lange, Kant's ethical 'categorical imperative' too, needs to be revised according to this new scientific-materialist thinking:

Thus in Kant, whose ethics materially very nearly coincide with those of Comte and Mill, but, nevertheless, are very sharply distinguished from any other utilitarian doctrine by the fact that the moral law is regarded as given a priori. As to the truth of this doctrine, it will be in much the same case as the truth of the doctrine of the Categories. The deduction of the principle is incomplete, the principle itself capable of improvement; but the germ of this consideration for the whole must be given in our organization prior to all experience, because otherwise the beginning of ethical experience would be altogether inconceivable. The principle of ethics is, a priori, not indeed as a ready-made, developed conscience, but as an arrangement in our original

1 Kant, 2004, pp. 133-134.

2 It is appropriate here to refer to recent studies of this naturalistic development of Nietzsche's thinking. For his relation to Darwin: Richardson (2004); Stegmaier (1987) is also of interest. For his place within the general intellectual environment of his time: Moore (2002). For a general account of the history of Darwinism and Evolutionary Theory, Mayr (1991) is excellent. 
disposition, the nature and operation of which, like the nature of our body, we can only gradually and a posteriori learn partially to know. ${ }^{3}$

It is explicitly the moral Law's a priori status that bothers the materialist. This a priori principle of ethics needs at least to be reduced to its barest formal minimum. It may be a part of our original disposition, but must be seen as a principle that develops according to learning-processes that are a posteriori. As such, Lange wants to introduce a materialistic and psychological foundation of the ethical principle - a foundation, Lange does not believe necessarily entails a defense of egoism, as had been frequently argued as a contentious point, but can include also the development of an altruistic and sympathetic disposition (as had been advocated by for example Auguste Comte and Herbert Spencer). ${ }^{4}$

We have already found that from a rigidly Materialistic view of things by no means only the principle of Egoism may be deduced, but also the great counterpoise to it, Sympathy. Both principles, without any influence of transcendental ideas or superstitious assumptions, may simply be deduced from the sensuous nature of man, and he who favors them may still be, in the full extent of the word, a Materialist. Kant's moral principle must, however, at least be brought down from the height of its a priori validity, and be established on a purely psychological basis, if it is to be harmonized with Materialism. ${ }^{5}$

To Lange, both Egoism and Sympathy have a material basis in the "sensuous nature of man," and they do not need the help of transcendental or "superstitious" assumptions, i.e., Kantian categories, which rather need to "be established on a purely psychological basis."

We notice how this debate is present also in Nietzsche when he in his discussion of morals implicitly or explicitly posits himself against Kant's metaphysics of morals (we will return to Nietzsche's take on this 'egoism/ altruism' distinction below). Nietzsche believes in a "moral law within us" no less than Kant does; regarding its mental representation and existence there can be no doubt. Still, in Nietzsche, we find a significant different explanation and analysis of the 'moral law' than in Kant.

Nietzsche is like his contemporaries committed to an evolutionarynaturalistic perspective. He may be a Lamarckian rather than a Darwinian in his naturalism, but the contemporary paradigm-shift toward an evolving rather than a static, a relational rather than a substantial, world is always defended. 
Nietzsche's moral law evolves as 'conscience' (or "formal conscience") phylogenetically, i.e., through civilization and socialization processes. 'Conscience' and the ability to exercise moral judgments become an outcome of a historical process, and the 'moral imperative,' the Kantian 'sense of duty,' emerges as a result of these processes. In Nietzsche, as in Freud (who in "Civilization and its Discontents" often appears to be paraphrasing Nietzsche), ${ }^{6}$ conscience is a restraining and disciplining capacity that develops as a response to the emergence of civilizations and societies, and thanks to which humans, within these closed and regulated communities, increasingly are made accountable and predictable, and eventually rational. Significantly, rationality becomes an effect of disciplinary procedures, not an inert human precondition.

\section{Law Given as Command}

Thus, the 'moral judgment' is in Nietzsche not object of the same unreserved admiration as we find it in Kant. In Nietzsche, the moral laws giving content to conscience have been issued as commands with no rational foundation, and primarily to restrain the human being. Conscience is neither 'the voice of God in man,' nor is it Kant's 'voice of reason in man'; it is instead, "the voice of some men in man"; from its former divine or metaphysical heights, it is brought down to earth:

Content of the conscience. - The content of our conscience is everything that was during the years of childhood regularly demanded of us without reason, by people we respected or feared. It is a conscience that excites the feeling of obligation ('I must do this, not do that'), while not asking: why must I? [...] The belief in authorities is the source of the conscience: it is therefore not the voice of God in the heart of man but the voice of some men in man. (MA II/2, 52, KSA 2, p. 576)

Considering that obedience so far has been best and longest practiced and cultivated amongst humans, it is easy to suppose that, by now, the average person has developed an innate need to obey, a kind of formal conscience [formalen Gewissens] that commands: 'you shall unconditionally do something, unconditionally not do something,' briefly, 'you shall.' This need tries to satisfy itself and to fill its form with a content; like a crude appetite, it indiscriminately grabs up [...] whatever is shouted into its ear [in's Ohr gerufen wird] by some commander - parent, teacher, law, class prejudice, public opinion. (JGB 199, KSA 5, p. 119)

The second inquiry [of GM] offers the psychology of the conscience - which is not, as people may believe, 'the voice of God in man.' (EH 'Zur Genealogie der Moral", KSA 6, p. 352)

6 Nietzsche scholars are well aware of these 'family-resemblances' between Nietzsche and Freud. Leiter (2002) mentions it. The authoritative account on the relationship between Nietzsche and Freud I still regard to be Gasser (1997). See also, Paul-Laurent Assoun (2000). 
Nietzsche sees Kant as continuing the Christian paradigm by essentially internalizing the divine as rational principle; Christian commandments are being replaced with rational imperatives; religious beliefs are transformed into rational syllogisms, but to Nietzsche's mind, without freeing themselves from their genealogical origin in the 'servile' need of an unconditional authority. In FW, "Faith is always coveted most and needed most urgently where will is lacking; for will, as the affect of command, is the decisive sign of sovereignty and strength. In other words, the less someone knows how to command, the more urgently does he covet someone who commands, commands severely." (FW 347, KSA 3, p. 582). We notice that the 'commander,' who in this passage is described as 'sovereign,' seems indistinguishable from the commander who 'shouts' his commands 'into our ears' in JGB. We shall return to the issue in the description of the sovereign from GM.

With Kant's appeal to a rational soul, God's laws supposedly already exist inside us as rational categories. 'You shall not kill', 'you shall not lie,' etc., are no longer merely commandments pronounced by God as externality, but internal rational principles, which we shall find locked within us if we look closely enough. God, the "categorical imperator," is by Kant transformed into a 'categorical imperative':

An authority speaks - who speaks? - One may forgive human pride if it sought to make this authority as high as possible in order to feel as little humiliated as possible under it. Therefore - God speaks! One needed God as an unconditional sanction, with no court of appeal, as a "categorical imperator" - or, if one believed in the authority of reason, one needed a metaphysic of unity [Einheits-Metaphysik], by virtue of which this was logical. (WM 275, p. 196)

When Nietzsche explains Kant's categorical imperative psychologically and naturalistically, the unifying metaphysical rationality of the moral law is undermined, and moral law becomes, instead, the voice of an arbitrarily imposed 'reason' in man (cf. MA II/2 above: "The content of our conscience is everything that was during the years of childhood regularly demanded of us without reason"). All these "thou shalt," which have been "shouted into our ears" since childhood will continue to live on in the adult as internalized ideals and laws to be fulfilled (the child will become 'the father of the adult,' Freud said a few decades later). Thus, we see that Nietzsche's 'conscience' inspires a sense of obligation, duty, and respect for Law no less than Kant's, but it does so as command and demand, which, contrary to Kant, has no rational justification. 


\title{
3 The Splitting of the Subject by Law
}

Such an internalized moral law projects itself in action and deed unconsciously, and it divides the self up in two conflicting parts, with one part set over and against the other part. As such it also destroys the delusion about a unified and homogeneous subject, as Nietzsche explains in MA

\begin{abstract}
Morality as self-division [Selbstzertheilung] of man. - [...] A soldier wishes that he falls on the battlefield for his victorious fatherland; for in the victory of his fatherland is his highest desire triumphant. A mother gives to her child that which she deprives herself, sleep, the best food, if need be her health, her strength. $-[\ldots]$ Is it not clear that in all these instances man loves something of himself, an idea, a desire, an offspring, more than something else of himself, that he as such divides his nature and sacrifices one part of it to the other? [...] - The inclination for something (wish, drive, demand) is present in all the above-mentioned instances; to give in to it, with all the consequences, is in any event not 'unegoistic'. - In morality man treats himself not as individuum but as dividuum. (MA 57, KSA 2, p. 76)
\end{abstract}

According to Nietzsche's naturalization of morality, we have undergone an evolution during which the human being has been introduced to Law, which has eventually been internalized - the result being that the formerly uncomplicated individuum has been transformed into a dividuum. Nietzsche assumes, in the cases he mentions, that the individuals have some immediate 'egoistic' self-interests and inclinations - the soldier wants life; and the mother wants health - which are nevertheless contradicted by a moral law that dictates the agents to act contrary to own immediate interests in the name of some other, more abstract, principles: the soldier's fatherland and the mother's child. In Nietzsche's two examples, one might indeed suggest, in paraphrase of Kant, that immediate egoistic 'inclinations' are thwarted because of a 'sense of duty'; and one might be inclined to think that Nietzsche has provided us with a couple of felicitous examples of the Kantian categorical imperative.

However, this is not Nietzsche's intention. Although Nietzsche's Law dictates a 'sense of duty' no less than Kant's, Nietzsche goes on proposing that both of the two positions are 'egoistic states,' where the plain (biological) survival self-interest in the first position has been replaced with a more abstract (ideological) self-interest in the second. He does not conceive of one of the positions as 'egoistic' and the other 'altruistic.' It is clear that in the second position, man expresses a love of something in himself that is stronger than his love of something else in himself. As such, Nietzsche's moral subject is split, but in two egoistic parts. He presupposes that the moral subject is no longer whole and unified. When an individual is transformed into dividuum, it becomes perfectly possible for an egoistic interest to develop in each of the 
divided parts; i.e., one egoistic interest can develop in naked contradiction to another egoistic interest. In a split subject, $A$ and non- $A$ may exist side by side.

\section{Before the Law and Beginnings of Law}

When undergoing moral "self-division," the subject splits itself by adopting a Law that is not its own and not in its own most obvious interest, but which, nonetheless, directs some of its actions as Ideal. The individual must now obey this ideological 'something,' besides obeying its more immediate self-interests, which are often in Nietzsche, biological instincts for survival. It is, of course, the institution of the moral-ideological Law that he finds most interesting, since instincts for survival are regarded as constitutional.

In historical or evolutionary terms, Nietzsche imagines a situation preceding the moral-ideological Law, a situation before the splitting of the subject. If moral law emerges from an authority among men, i.e., from a commander "shouting" his commands into our ears, there must have been a human condition before the introduction of Law. A human type preceding the constitution of the law-abiding subject must evidently have been law-less, and Law must be a later addition imposed on this originally lawless subject.

These questions about what is 'before the Law' and what the 'beginnings of Law' are some of the questions taken up in GM, part II. Here Nietzsche is famously attempting to describe both the original constitution of the lawless subject that cannot yet make and keep promises, and the means by which this subject is taught to commit itself to a first few commandments. In GM II, 2, we also learn about a human type that seems to stand out from the general condition of the crowd by being able to impose Law both upon himself and others, the so-called 'Sovereign individual' - the one exceptional individual who seems to be in command of Law. This figure, who is said to be 'autonomous' and endowed with 'free will,' has recently excited vigorous debate among Nietzsche-scholars, especially from the Anglo-Saxon tradition (with participants such as Christa D. Acampora, Ken Gemes, Lawrence Hatab, Christopher Janaway, Brian Leiter, Paul Loeb, Simon May, John Richardson, \& Aaron Ridley). ${ }^{7}$

We shall start suggesting that Nietzsche's introduction of two concepts from GM II, 1, 'forgetfulness' and 'memory,' may function as labels for the two main issues discussed in the present section, Before the Law and 
Beginnings of Law. They will also help us in an understanding toward his much-debated concept of the 'Sovereign.' With this focus on forgetfulness and memory, we notice that we are again back discussing biology, physiology, and psychology; Nietzsche, read in this naturalistic context, may very well be seen as foreshadowing contemporary insights in cognitive science and neuropsychology. ${ }^{8}$

It is plain that for a Law or an Idea to be effectual, the individual must have evolved a memory-system. Law or Idea cannot impose themselves on the individual as instinct (conceptually, Idea and Instinct are mutually exclusive), but can only come about from learning processes that necessarily, in order for them to have been learnt, must be remembered. Before Law, there is forgetfulness, and a lawless subject must be a forgetful subject, while a lawabiding subject must be a subject that has learnt to remember.

Let us keep that small deduction in mind when we read the first sentence of GM II. Accordingly, the task is to "breed an animal with the right to make promises" - in Walter Kaufmann's translation of the German, "ein Their heranzuzüchten, das versprechen darf". The emphasized phrase returns during GM II, 2 when Nietzsche describes the sovereign individual as (still Kaufmann's translations): "the man who has his own independent, protracted will and the right to make promises [der versprechen darf]"; and again, "this emancipated individual, with the actual right to make promises [der wirklich versprechen darf]"; and finally, "the strong and reliable (those with the right to make promises [versprechen dürfen]) - that is, those who promise as sovereigns."

The translation of especially the 'darf/dürfen' in these passages has been widely debated. Are we here talking about a 'right' as in Kaufmann - or in other translators, an 'entitlement' (Douglas Smith) or 'permission' (Clark \& Swensen)?' Is 'dürfen' here to be understood as being allowed to, as having a right/permission to (as in erlauben sein), or is it rather understood as having an ability or a capacity to (as in fähig sein)? The translation is important, because if we assume that something is giving the sovereign a 'right' or a 'permission' to make a promise, we automatically presuppose an agency wielding such an authority - for example, in the form of a society with its political, legal, and religious institutions.

8 One Nietzsche scholar in particular, who better than anybody has taken Nietzsche in these directions is philosopher Günter Abel. See for example Abel (2001).

9 I am here referring to the following three English translations of "The Genealogy": M. Clark \& A. Swensen (Hackett, 1998); D. Smith (Oxford University Press, 1996b); and W. Kaufmann (Vintage Books, 1969). 
In the 'weaker' translation of dürfen, as 'having an ability to' (which English translators largely ignore), agency is not relevant, and nobody would presume that the sovereign has received any right, entitlement, or permission to make promises. In saying somebody has 'an ability' to do something, we are talking about a physiological or neurological disposition that suggest no agency. ${ }^{10}$ The translation makes no room for a sovereign for the sovereign, a lawgiver for the lawgiver. The Sovereign (capitalized) becomes the original giver of Law. This reading, we defend as the most logical, but also the most scientific, because it implies that we can stay focused on Nietzsche's naturalistic and evolutionary perspective, according to which he assumes that some prehistoric individuals eventually acquire the important capacity to make promises and to keep them. ${ }^{11}$ On this reading, Nietzsche's rhetoric about the sovereign's mastery is perhaps not as exaggerated as has been suggested, because the development of memory must be seen as a sea-change

10 Matthew Rukgaber is aware of this 'weaker' translation-option, but seems unaware of its implications: "If the SI is allowed to promise or is granted permission, then the question arises, who permits? The natural answer is that permission derives from the Sl's actual ability to live up to the standard of keeping one's promise, although that raises the question of why a far more ordinary construction indicating ability ("können," "to be able") is not used [my emphasis]" (Rukgaber, 2012, p. 225). Brian Leiter seems to agree with the expediency of a weaker translation of darf/dürfen, and its general naturalistic implications: "Nietzsche begins the Second Essay of the Genealogy with a characteristically naturalistic question: how to "breed an animal" [ein Thier heranzuzüchten] which is able [sic!] to make and honor a promise? The assumptions underlying this question are twofold. First, and most obviously, human beings are certain kinds of animals. And second, as with other animals, one explains what they do (e.g., promise-making) not by appeal to their exercise of some capacity for autonomous choice and decision, but in terms of the causal mechanisms (e.g., breeding) acting upon them, which yield certain steady behavioral dispositions" (Leiter, "Who is the 'sovereign individual'? Nietzsche on freedom." 2010. Available at, http://ssrn.com/ abstract $=1473095$, p. 8).

11 Several prominent commentators from the Anglo-Saxon tradition have offered interpretations of Nietzsche's Sovereign Individual. Paul Loeb calls the Sovereign "the ripest fruit of humankind's entire prehistoric labor" (Loeb, 2005, p. 77), and situates him as such as an end-product of an early historical process (like undersigned). Other commentators believe rather that the Sovereign indicates Nietzsche's hope for a future man to come; so Ridley (1998). Ken Gemes is ambivalent as to whether the Sovereign represents an ideal of the past or the future: "It is not at first clear whether the sovereign individual is a creature already achieved or one yet to come" (Gemes \& Janaway, 2006, p. 326). May (1999) believes Nietzsche is ironic in his description of the sovereign, because it is at odds with his usual emphasis on human contingency. Brian Leiter suggests, along the same lines but only as hypothesis, that Nietzsche might be ironic in his introduction of the Sovereign: "One might be tempted to conclude that this whole passage is little more than a parody of the contemporary bourgeois who thinks that he has achieved something "unique" something individual - just because he is steady enough to make a promise and honor it" (Leiter, ibid., p. 11). Acampora (2004) seems more convinced that Nietzsche cannot mean what he is saying, and that contrary to his glorification of the Sovereign, Nietzsche is not advancing him as an ideal of superiority. Again, the sovereign does not correspond to Nietzsche's usual description of the human as fragmentary and changing; it also does not correspond to the description of 'active forgetting' as a positive capacity described in the preceding section; finally, the sovereign's responsibility and accountability seems to Acampora to be typical characteristics of slave-morality. Paul Loeb also thinks that Nietzsche "depreciates" the sovereign, but in contrast to Acampora, because he is not "responsible and autonomous enough" - compared to the superhuman (Loeb, 2005, p. 79). To deal with these and other interpretations of the Sovereign in better detail would make up for an essay in itself, which, interesting as it is, must be deferred to another time. 
in human evolution. After all the original human forgetfulness and mental chaos Nietzsche describes in the first paragraph (GM II, 1), in the second paragraph, some "sovereign individuals" emerge with an ability to remember commitments, they emerge with a "memory of their will."

However, as we shall discuss below, it remains a mystery how 'sovereigns' emerge with this particular ability. From an evolutionary perspective, it is unexplained why some rare individuals within a species evolve with an ability to remember, but the greater majority does not.

\section{The Arbitrariness of Law}

In explaining Nietzsche's notion of forgetfulness, we may just as well start by determining what it is not. It is hardly, as Brian Leiter describes it, the same as 'repression," 12 which is a negative operation involving the suppression of a painful or traumatic experience. Most fundamentally, Nietzsche's forgetfulness is inert (not a reaction to painful experiences), implying the fact that we, neurologically speaking, are able to process only limited amounts of information. Our mental system is, by default, a 'simplification-apparatus.' If the notion corresponds to any concept in psychoanalysis, it comes closest to Freud's concept of the 'pre-conscious' (as the storage of material not present in the conscious-system, but stored away in memory systems). As such, it is indeed 'healthy' and 'necessary' as Nietzsche says. Impressions impinge themselves on our sensory system in too large a number, and our 'defense' is to 'forget them' - they are either only conscious for a brief moment and then stored away as memories, or they never enter our systems for conscious processing. In this primary sense of forgetfulness, there would be no (sense of) presence without forgetfulness, as Nietzsche significantly tells us (cf. GM II, 1), because if we remembered everything, our system would be inundated in a chaos of past and present experiences, and the subject would be incapable of disentangle the present from the past.

In a second sense, there is forgetfulness as "active forgetfulness," which cannot be the same as pre-consciousness, but is rather the voluntarily adopted disregard of the unpleasant as a condition for maintaining a cheerful attitude to life. Forgetfulness gives the early individual a certain happy and cheerful attitude to life, an ability to live and enjoy the immediate present, which is later lost. If thus in the philosophical tradition, forgetfulness has been determined theme: the human capacity for repression" (Leiter, 2002, p. 228). 
negatively, it is in Nietzsche a positive quality belonging to the active order of things. It is a healthy and indeed necessary repression of memorized material. It forces the mental system to close down, shut out superfluous material, and with this, make room for new things. "Active forgetfulness" is not least a positive quality, insofar as it makes possible decisiveness in action. The healthy individual is not bugged down and incapacitated in action by having to digest too much information before acting. Able to 'forget' and 'simplify' superabundant information, he/she acts in the instant. A certain superficiality in the individual is a sure sign of healthy instincts.

Forgetfulness is no mere vis inertiae as the superficial imagine; it is rather an active and, in the strictest sense, positive capacity for repression. It is responsible for the fact that what we see and experience enters our consciousness as little, while we are digesting it, as does the thousand-fold process related to physical nourishment - so-called 'incorporation' [Einverleibung]. To close the doors and windows of consciousness for a while; to remain undisturbed by the noise and struggle of our underworld of utility organs working with and against one another; a little quietness, a little tabula rasa of the consciousness, to make room for new things, $[. .$.$] that is the$ purpose of active forgetfulness [aktiven Vergesslichkeit], which is like a doorkeeper, a preserver of psychic order, repose, and etiquette. So it becomes immediately obvious that there would be no happiness, no cheerfulness, no hope, no pride, no present, without forgetfulness. (GM II 1, KSA 5, p. 291)

In the most fundamental sense, Nietzsche's human being is constitutional forgetful, and it is this constitution that makes discipline and punishment necessary in the history of civilization. The forgetful individual has to learn to remember a few rules. Knowledge is acquired painstakingly and painfully; and in most cases, memory of Law has to be imprinted by means of punishment, discipline, and torture. Rules are written in blood. This is how the majority of Nietzsche's prehistoric population learns to remember. This is a theme from "The Genealogy of Morals" that is well-rehearsed by commentators, and which we shall not delve into any further.

However, it is at this point we seem to encounter a conundrum, because there is apparently in Nietzsche's genealogical narrative another, seemingly, competing explanation on the emergence of memory, namely in the figure of the sovereign, from GM II, 2, who is somehow originally equipped with the capacity to internalize, all by himself, duty and commitment (i.e., remember).

As we read GM II, 1, we understand that constitutional forgetfulness is an inert, fundamental, and original condition; but then we read GM II, 2, and are told that from these constitutionally forgetful humans, a sovereign individual arises able to remember his word and act upon it, i.e., able to make promises and keep them. From the abyss of a chaotic psyche, originally nothing but 
a confusion of opinions, valuations, drives, and emotions, the sovereign (somehow) impresses upon himself responsibility and accountability by forcing himself to remember a word; and this becomes the mark of his excellence. ${ }^{13}$ The sovereign (somehow) memorizes self-imposed Law in form of a word, while the emotional slave memorizes past feelings associated to pains and insults suffered in the past. The intersected 'somehow's must be the crucial and contentious issue of discussion, because we are never told how the sovereign manages to generate this self-discipline; this "memory of his will."

The man [the sovereign individual] who has his own independent, protracted will and the right to make promises - in him a proud consciousness, quivering in every muscle, has at length been achieved and become flesh; a consciousness of his own power and freedom, a sense of the completion of mankind. This emancipated individual, with the actual right to make promises, this master of free will, this sovereign man [...] looks out upon others he honors or despises, and just as he is bound to honor his peers, the strong and reliable (those with the right to make promises) (- that is, all those who promise like sovereigns, reluctantly, rarely, slowly, who are hesitant in trusting, all those whose trust is a mark of distinction, who give their word [sein Wort giebt] as something that can be relied upon. (GM II 2, KSA 5, p. 293)

On the one hand, we must maintain that there can be no sovereign for the sovereign, because otherwise, we need an explanation of this earlier agency, and we are simply entering a vicious circle of infinite regress. One the other hand, the sovereign's self-generation of self-discipline remains unexplained in Nietzsche's narrative (we shall return to the problem shortly and suggest a formal quasi-explanation).

\section{The Incipients and Recipients of Law; Another Master-Slave Figure}

Nietzsche's commander is in some contexts depreciated, in other contexts, appreciated. In the passage from JGB above, value is withdrawn when he as "parent, teacher, law, class prejudice, public opinion" 'shouts' his commands into the ears of subdued and repressed servile subjects. When Nietzsche's commander as priest, e.g., in GW III, "pours his poison" into the ears of his congregation, he is most definitely depreciated and devalued. However, in the figure of the 'Sovereign,' the commander changes value, and now he is evidently appreciated.

13 Cf. Werner Stegmaier: "Understood in Nietzsche's sense, forgetfulness is no longer an incapacity of the intellect, but rather a force necessary for life and enabling life. As Nietzsche recognizes, it is necessary for life to hold back information from consciousness, not only in order to focus our attention, but also to fade down concerns that are always bound to paralyze action" (Stegmaier, 1994, p. 135). 
In form of the Sovereign, we are introduced to a figure with a strong sense of duty and commitment; with an ability to make and keep promises, in contrast to the "feeble windbags" [schmächtigen Windhunde] who forget their promise in the very instant they utter it. The rhetoric suggests a new master-slave relationship, although not explicitly represented in these terms. The talkative windbag is despicable because he is unable to impose a law upon himself that binds him to keep his promises. The sovereign, by contrast, is now the "emancipated individual, with the actual ability/right to make promises"; he is a "master of a free will [...] aware of his superiority over all those who lack the ability/right to make promises" (cf. GM II, 2). ${ }^{14}$

They [the sovereigns] give their word [sein Wort giebt] as something that can be relied upon because they know themselves strong enough to maintain it in the face of accidents), [...] he [the sovereign] is bound to reserve a kick for the feeble windbags who promise without the ability/right to do so, and a lash for the liar who breaks his word [sein Wort bricht] in the very instance he utters it. (GM II 2, KSA 5, p. 293)

In Nietzsche's Sovereign, we encounter a 'master-figure' (albeit possibly not equivalent to the Übermensch, as has been argued) that institutes law in order to restrain the resentment of the 'slave.' We have a 'stronger power' that dams up the indiscriminate rage and vengefulness of the 'weaker power' by instituting 'justice.' Justice is explicitly preferable to a human chaos of reactive feelings.

From a historical point of view, law represents on earth [...] the struggle against the reactive feelings. [...] Wherever justice is practiced and maintained one sees a stronger power seeking a means of putting an end to the senseless raging of ressentiment among the weaker powers that stand under it. [...] The most decisive act that the supreme power performs and accomplishes against the predominance of grudges and rancor $[\ldots]$ is the institution of law. (GM II 11, KSA 5, p. 311-12)

Emerging from the human abyss of nothingness, justice becomes a universal standard measuring human action. The sovereign, who is also a master in objectivity and neutrality, applies this universal standard as much to himself as to fellow human beings.

14 In this particular passage it seems legitimate to return to Kaufmann's translation of darf/dürfen as right, insofar as the ability to make a promise, gives the sovereign a right to do so, whereas the inability would withdraw this right, since claiming it would come under false pretences. From Nietzsche's aristocratic perspective, one has no right to pretend to be able to do what one is not able to do. l.e., the frivolous has no right to pretend to be virtuous, the liar has no right to pretend to be truthful, and the irresponsible has no right to pretend to be responsible. 
The last sphere to be conquered by the spirit of justice is the sphere of the reactive feelings! When it really happens that the just man remains just even toward those who have harmed him [...] when the exalted, clear objectivity, as penetrating as it is mild, of the eye of justice and judging is not dimmed even under the assault of personal injury, derision, and calumny, [then] this is a piece of perfection and supreme mastery on earth. (GM II 11, KSA 5, p. 312)

In this statement, Nietzsche's 'master on earth' is a man who understands to act according to duty, who sets Law above his own immediate desires, inclinations, and concerns. He is an example of Nietzsche's active order directed against reactive feelings, the anarchism of resentment and envy.

\section{Nietzsche Pro/Con Kant?}

This strong endorsement of the sovereign is not the least puzzle to commentators. The figure of the sovereign, which is rather unique in Nietzsche's repertoire of characters, with his strong sense of duty, commitment, and accountability, seems to compare favorably to Kant's moral subject. As has been often noted, in the Sovereign, we seem to encounter a self-conscious, autonomous, morally obligated individual, which is uncharacteristically Kantian. ${ }^{15}$ It seems that Nietzsche for a moment is adopting Kant's rigorous command-morality in his praise of a rational and moral subject that is able to detach itself from its inclinations and desires, able to act according to a 'duty', transgressing and sacrificing the 'dear self' for the long-term, communal, or social benefits of an action. It is clear from the passage that one of the problems with the 'slaves' is their emotional unpredictability. They are incapable of acting according to Law, because Law is always being overridden by their immediate passionate-egocentric projects. They cannot make any promises (and have therefore, in hyperbolic terms, no right to do so) because they, with their chaotic-passionate-resentful selves, primarily, would forget their promises and, secondarily, would not care about committing themselves should they happen to remember. ${ }^{16}$

15 E.g., "Attempts to reconstruct a Nietzschean ethic based on the SI passage have resulted in uncharacteristically Kantian results, because of the deontological nature of promising in the SI passage" (Rukgaber, 2012, p. 213).

16 Ken Gemes (in Gemes, K. \& Janaway, C.: "Nietzsche on Free Will, Autonomy and the Sovereign." (2006)), who assumes Nietzsche is addressing his reader, 'you' (what I find doubtful), puts the thought as follows: "you are not sufficiently whole to have the right to make promises; you have no free will, but are merely tossed about willy-nilly by a jumble of competing drives, and, hence, you cannot stand surety for what you promise. You can give no guarantee that the ascendant drive at the time of your making a promise will be effective when the time comes to honor that promise" (Gemes \& Janaway, 2006, p. 327). Christopher Janaway, with his usual careful hermeneutics, is expressing a similar thought: "To be permitted to make 
No wonder commentators object in bewilderment, if Nietzsche usually says that we are by nature chaotic, fragmented, irrational, unpredictable, and selfish, how come that the Sovereign's rational and unselfish qualities all of a sudden are back to prominence as valued and appreciated? Is not Nietzsche, in this odd revaluation of a previous revaluation of values, contradicting his many scathing comments on Kant's metaphysics of morals and its appeal to the 'good will'?

Let us finally submit three comments on the conundrum that cannot aspire to resolve it, but perhaps rather give it formal representation and suggest guidelines for further research.

First: Let us recall Hume famous dictum, an 'ought' cannot logically follow from an 'is' (nor an 'is' from an 'ought'). Similarly, let us not confuse Nietzsche's 'is' with his 'ought.' From Nietzsche's description of inert human 'irrationality,' it does not follow that he believes humans ought to be irrational; and from Nietzsche's many critiques of philosophers who advocate inert human 'rationality,' it still does not follow that he believes that humans ought to be irrational. In the way Nietzsche articulates the problem, the distinction rational/irrational is not the main issue, but becomes merely a later conceptualization of the more fundamental ability (or right) to keep one's word.

Second: The Sovereign keeps his word because he wills it so. This will is not 'good' and is not calculated to be rational. It is merely penetrating, as a single ray of light, a dark and opaque self; it is like a single thought (a single obsession, for that sake) in a confusion of thoughts, which the commander commands himself to obey. It is the Sovereign's ability to recognize and exercise this one thought in his chaotic self that makes him 'proud.'

Third: When the commander externalizes that command he first applies to himself, and applies it to the crowd of our confused ancestors as Law, it is neither a Law issued by God, nor by a unifying categorical-rational principle. Its 'universality' is lacking, because its authority is constituted merely in the enunciation of the command itself. The 'command' is the ultimate performative. It is a performative act that demands that another performative act, namely the promise, is to be taken seriously. As such we are far removed

promises, one must not only be minimally capable of promising, but have the power to fulfill one's promises and the integrity to promise only what one genuinely has the will to do. This suggests a kind of selfknowledge in which one is properly conscious of what it is that one wills, and confident of the consistency with which one's will is going to maintain itself intact until the moment at which it can be delivered upon. The sovereign individual can count upon himself to act consistently, to be the same in the future when the time comes to produce what he promised in the past" (Gemes \& Janaway, 2006, p. 351). 
from supposed truth-claims of Law. As the speech-act philosophers (e.g., Austin and Searle) have convincingly demonstrated, the performative makes no claims to truth. Enunciating Law, the commander, the Sovereign, must therefore in his own self personify 'truth'; i.e., he must personify pure will insisting that a pure performative has veridical constative content.

This seems to be Nietzsche's explanation of the 'beginnings of law' beginnings located in pure will (and not Kant's 'good will,' which becomes entirely irrelevant). Nietzsche, with his usual requirement for the consistency and coherence of his philosophical narratives, needs to ground his discourse and to describe a first cause for the institution of Law. His institution of Law becomes the very un-Kantian Sovereign 'shouting' his commands into the ears of his weaker fellow beings - in this 'shouting' insisting on the veridical content of his performative acts for himself and his fellow beings. Law is dependent on somebody extremely willful and powerful; therefore, it is arbitrary, but arbitrary law seems in Nietzsche to be better than no law at all.

\section{Bibliography}

ABEL, G. "Bewußtsein - Sprache - Natur. Nietzsches Philosophie des Geistes." In: Nietzsche-Studien. Band 30. Berlin/New York: Walter de Gruyter, 2001.

ACAMPORA, C. D. "On Sovereignty and Overhumanity". In: C. D. Acampora (ed.). Nietzsche's "On the Genealogy of Morals": Critical Essays. Lanham: Rowman/ Littlefield, 2006.

ASSOUN, P.-L. "Freud and Nietzsche". Translated by R. L. Collier. London: The Athlone Press, 2000.

BORNEDAL, P. "The Surface and the Abyss: Nietzsche as Philosopher of Mind and Knowledge”. Berlin/New York: De Gruyter, 2010.

CONWAY, D. "Nietzsche's 'On the Genealogy of Morals"'. London: Continuum, 2008.

FREUD, S. (1930). "Civilization and its Discontents". In: The Standard Edition. London: The Hogarth Press, 1966. vol. 12.

GASSER, R. "Nietzsche und Freud". Berlin/New York: Walter de Gruyter, 1997.

GEMES, K.; JANAWAY, C. "Nietzsche on Free Will, Autonomy and the Sovereign." Proceedings of the Aristotelian Society, Supplementary Volumes, Vol. 80, 2006.

GEMES, K.; MAY, S. (ed.). "Nietzsche on Freedom and Autonomy". Oxford: Oxford University Press, 2009.

HATAB, L. "Nietzsche's 'On the Genealogy of Morality': An Introduction". Cambridge: Cambridge University Press, 2008.

HIMMELMANN, B. (ed.). "Kant und Nietzsche im Widerstreit". Berlin/New York: Walter de Gruyter, 2005. 
JANAWAY, C. "Beyond Selflessness: Reading Nietzsche's 'Genealogy"”. Oxford: Oxford University Press, 2007.

KANT, I. "Critique of Practical Reason". Translated by M. McGregor. Cambridge: Cambridge University Press, 1997.

KANT, I. "Metaphysics of Morals". Translated by M. McGregor. Cambridge: Cambridge University Press, 2000.

KANT, I. "Grounding of a Metaphysics of Morals". Translated by J. W. Ellington. New York: Hackett Publishing Company, 1993.

LANGE, F. A. (1865). "The History of Materialism". Translated by C. K. Ogden. New York: Routledge, 2000. vol. 3. Original Text: "Geschichte des Materialismus". Iserlohn: Verlag con J. Daedeker, 1873. Bd. 3.

LEITER, B. "Who is the 'sovereign individual'? Nietzsche on freedom." Cambridge Critical Guide to Nietzsche's On the Genealogy of Morality. Ed. S. May, 2010. Available at SSRN: http://ssrn.com/abstract=1473095.

LEITER, B. "Nietzsche on Morality". London/New York: Routledge Philosophical Guidebook, 2002.

LOEB, P. "Finding the Übermensch in Nietzsche's Genealogy of Morality". Journal of Nietzsche Studies, 30, 2005.

MAY, S. "Nietzsche's Ethics and his 'War on Morality". Oxford: Oxford University Press, 2000.

MAYR, E. "One Long Argument: Charles Darwin and the Genesis of Modern Evolutionary Thought". Cambridge, Harvard University Press, 1991.

MILES, T. "On Nietzsche's Ideal of the Sovereign Individual”. International Studies in Philosophy, 39/3, 2007.

MOORE, G. "Nietzsche, Biology and Metaphor". Cambridge: Cambridge University Press, 2002.

MÜLLER-LAUTER, W. "Über Freiheit und Chaos: Nietzsche-Interpretationen II". Berlin: New York: Walter de Gruyter, 1999.

NIETZSCHE, F. "Sämtliche Werke Kritische Studienausgabe" [KSA]. Ed. G. Colli and M. Montinari. Berlin/New York: Walter de Gruyter, 1967-1977.

NIETZSCHE, F. "Menschliches, Allzumenschlisches" [MA]. KSA 2.

NIETZSCHE, F. "Die fröhliche Wissenschaft" [FW]. KSA 3.

NIETZSCHE, F. "Zur Genealogie der Moral" [GM]. KSA 5.

NIETZSCHE, F. "Jenseits von Gut und Böse" [JGB]. KSA 5.

NIETZSCHE, F. "The Twilight of the Idols". Translated by R. J. Hollingdale. London: Penguin Books, 1968a.

NIETZSCHE, F. "The Will to Power". Edited by W. Kaufmann. Translated by Kaufmann and R. J. Hollingdale. New York: Vintage Books, 1968b.

NIETZSCHE, F. "On the Genealogy of Morals". Translated by W. Kaufmann. New York: Vintage Books, 1969.

NIETZSCHE, F. "Beyond Good and Evil". Translated by R. J. Hollingdale. London: Penguin Books, 1973. 
NIETZSCHE, F. “The Gay Science”. Translated by W. Kaufmann. New York: Vintage Books/Random House, 1974.

NIETZSCHE, F. "Human, All Too Human". Translated by R. J. Hollingdale. Cambridge: Cambridge University Press, 1986.

NIETZSCHE, F. “Der Wille zur Macht” [WM]. Stuttgart: Kröner Verlag, 1996a.

NIETZSCHE, F. "On the Genealogy of Morals". Translated by D. Smith. Oxford: Oxford University Press, 1996b.

NIETZSCHE, F. "On the Genealogy of Morality". Translated by C. Maudemarie and A. Swensen. Indianapolis, IN: Hackett, 1998.

OWEN, D. "Equality, Democracy, and Self-Respect: Reflections on Nietzsche's Agonal Perfectionism." Journal of Nietzsche Studies, 24, pp. 115-116, 2002.

POELLNER, P. "Nietzschean Freedom.” In: GEMES, K.; MAY, S. (ed.). "Nietzsche on Freedom and Autonomy". Oxford: Oxford University Press, 2009.

RAFFNSØE, S. "Nietzsches 'Genealogie der Moral"'. Paderborn: Wilhelm Fink Verlag, 2007.

RICHARDSON, J. "Nietzsche's New Darwinism”. Oxford: Oxford University Press, 2004.

RIDLEY, A. "Nietzsche's Conscience: Six Character Studies from the Genealogy". Ithaca: Cornell University Press, 1998.

RUKGABER, M. "The 'Sovereign Individual' and the 'Ascetic Ideal'". Journal of Nietzsche Studies, Vol. 43, Nr. 2, 2012.

SCHACHT, R. "Nietzsche". London/New York: Routledge, 1983.

SCHACHT, R. (ed.). "Nietzsche, Genealogy, Morality: Essays on Nietzsche's 'On the Genealogy of Morals"'. Berkeley: University of California Press, 1994.

SMALL, R. "Nietzsche in Context". Aldershot: Ashgate, 2001.

STACK, G. "Lange and Nietzsche". Berlin/New York: Walter de Gruyter, 1983.

STEGMAIER, W. "Darwin, Darwinismus, Nietzsche. Zum Problem der Evolution." In: Nietzsche Studien. 16. Berlin/New York: Walter de Gruyter, 1987.

STEGMAIER, W. "Nietzsches 'Genealogie der Moral"'. Darmstadt: Wissenschaftlische Buchgesellschaft, 1994.

WHITE, R. "Nietzsche and the Problem of Sovereignty". Urbana: University of Illinois Press, 1997. 